\title{
PECULIARITIES OF TREATMENT OF PATIENTS WITH ONYCHOMYCOSIS WITH CONTRAINDICATIONS TO SYSTEMIC ANTIMYCOTICS
}

DOI: 10.36740/WLek202109108

\author{
Kseniia Suprun, Yanina Kutasevych, Iryna Oliinyk, Oleksii Bilozorov, Iryna Mashtakova, Olga Stuliy \\ SE «INSTITUTE OF DERMATOLOGY AND VENEREOLOGY OF NAMS OF UKRAINE», KHARKIV, UKRAINE
}

\begin{abstract}
The aim: To increase the effectiveness of treatment of patients with onychomycosis with contraindications to administration of systemic antifungal therapy.

Materials and methods: The study involved 63 patients with onychomycosis of the toes aged 18 to 72 years under supervision at the clinic of the Institute of Dermatology and Venereology of the National Academy of Medical Sciences of Ukraine, who were divided into groups: Group I (30 patients) received naftifine hydrochloride solution and cream; Group II (33 patients) additionally used nail kit mycosan and cytoflavin 2 tablets 2 times a day for 1-1.5 months. The study implied microscopic and molecular genetic examination of nail plates before treatment and starting from the 4th week every 2 weeks. The study included patients with onychomycosis with positive results of both microscopic and PCR studies. Mycological recovery was noted in case of coincidence of results of these studies.

Results: Mycological recovery in patients of Group II began in the sixth week in $6.3 \%$ and occurred in $100 \%$ of cases at the 24th week of treatment, depending on the severity and clinical form. The overall effectiveness of therapy at the 48th week reached $56.7 \%$ in Group I and $72.7 \%$ in Group II.

Conclusions: The developed method of treatment, which includes the use of naftifine hydrochloride solution and cream, nail kit micozan and cytoflavin, allows to achieve clinical and mycological recovery in $72.7 \%$ of patients and is a priority in the treatment of patients with onychomycosis with comorbid conditions.
\end{abstract}

KEY WORDS: onychomycosis, topical therapy, concomitant disorder, naftifine hydrochloride, rye serum extract

Wiad Lek. 2021;74(9 p.l):2070-2075

\section{INTRODUCTION}

Due to the consistently high incidence of onychomycosis worldwide, there is a need to use external antifungal agents that would be safe and effective $[1,2]$. This is especially true for the elderly and senile, as there is a general aging population [3], and age is important in connection with the peculiarities of clinical manifestations, comorbidity of onychomycosis, socio-economic and interpersonal problems affecting patients' adaptation and quality of life [4-6], determining the relevance and medical and social importance of this problem.

The only method in the treatment of onychomycosis is etiotropic, which aims to eliminate the pathogen and is based on the severity of onychomycosis, depending on its clinical form, the degree of subungual hyperkeratosis, the area involved in the nail plate, the rate of nail growth, age, severity of abnormality and presence of concomitant disorders $[7,8]$.

The effectiveness of systemic antifungal therapy is higher than that of topical, but its administration is limited by the risk of side and sometimes toxic effects associated with long-term use of therapeutic agents. In addition, systemic therapy is contraindicated in severe somatic diseases, during pregnancy, breastfeeding. Systemic antifungal therapy is not compatible with a number of therapeutic agents.
Most elderly or senile patients with onychomycosis have various comorbidities, including peripheral circulatory disorders, diseases of the digestive system, endocrine system, musculoskeletal system, metabolic disorders, which significantly limits the possibility of prescribing systemic antifungal agents. Topical antifungal therapy in this category of patients is the method of choice.

\section{THE AIM}

The aim of the study was to increase the effectiveness of treatment of patients with onychomycosis with contraindications to the administration of systemic antifungal therapy.

\section{MATERIALS AND METHODS}

The study involved 63 patients with onychomycosis of the toes aged 18 to 72 years, 38 men and 25 women under the supervision at the clinic of the Institute of Dermatology and Venereology of the National Academy of Medical Sciences of Ukraine. The duration of the disorder ranged from 1 month to 10 years or more.

Criteria for inclusion in the study were: the presence of informed consent, the age of patients over 18 years, the presence of lesions of the nail plates with fungal infection 
in patients with contraindications to treatment with systemic antifungals.

Exclusion criteria were: absence of informed consent, age up to 18 years, absence of laboratory confirmation of onychomycosis, the presence of somatic disorder in the acute stage.

The diagnosis was established on the basis of a thorough clinical and laboratory study. the study implied assessment of patients' presentation, history of the disease (duration, previous treatment, terms of healing, number of relapses, presence of concomitant disorders, use of therapeutic agents at the time of examination).

Examination of patients involved determination of the number of affected nail plates, their area, color, transparen$\mathrm{cy}$, thickness, integrity, the presence of cracks, the condition of the free edge of the nail plates, nail folds.

To determine the causative agent of onychomycosis, microscopic and molecular genetic studies of nail plates were performed before treatment and starting from the $4^{\text {th }}$ week every 2 weeks [9-11]. The study included patients with onychomycosis with positive results of both microscopic and PCR studies. Mycological recovery was noted in case of coincidence of results of these studies.

Treatment was as follows: 1) 1\% aqueous-alcoholic solution of naftifine hydrochloride (estezifin), which is able to quickly and freely penetrate into the channels and cracks of the nail plate, reaching a high concentration in the area of accumulation of fungi; 2) $1 \%$ cream of naftifine hydrochloride (estezifin), which is able to penetrate well into the stratum corneum and for a long time to create high concentrations there due to the presence of lipophilic components that improve this process; 3 ) topical agent containing rye enzyme filtrate (mycosan), which promotes the natural growth of the nail plate and improves the structure of the nails, reduces porosity and protects against pathogenic fungi, creating a water-soluble film; 4) an agents that improves microcirculation and is a metabolic energy corrector (cytoflavin), in combination with these agents.

The treatment regimen was as follows. After daily soap and soda baths and thorough drying, an aqueous-alcoholic solution of $1 \%$ estezifin was applied from the frontal-distal part of the nail plate 2 times a day. Mycosan serum was applied to the nail plate in the horizontal plane 2 times a day. In the nail folds and $1 \%$ estezifin cream was rubbed into the matrix of the nail plate 2 times a day. Once a week, after the soap and soda baths, the nail plates were cleaned.

Patients with onychomycosis were divided into groups representative of age, sex, severity. Group I included 30 patients (18 men, 12 women) who received topical therapy in the form of naftifine hydrochloride solution and cream of Group II included 33 patients (20 men and 13 women) who received combination therapy using naftifine hydrochloride solution and cream in combination with nail kit micozan and cytoflavin, which is a natural metabolite of the body, stimulating tissue respiration and is a metabolic energy corrector improving microcirculation, 2 tablets 2 times a day for 1-1.5 months.

\section{RESULTS}

The study showed that the group of patients suffering from onychomycosis under the age of 40 years, reached $9.5 \%$ of all patients, $41-50$ years $-20.6 \%$, $51-60$ years $-31.7 \%$, over 60 years $-38.2 \%$ (Table I). Thus, the patients predominantly were middle-aged and older (44 patients - 69.9\%).

Assessment of the disease history showed that $33.3 \%$ of patients (21 subjects) suffered from onychomycosis of the toes from 1 month to 5 years, $30.2 \%$ of patients ( 19 subjects) from 6 to 10 years. The duration of the disease was more than 10 years in $36.5 \%$ of patients ( 23 subjects).

Table I. Distribution of patients of experimental groups by age

\begin{tabular}{cccc}
\hline Age of patients, years & Group I, $\mathbf{n}=\mathbf{3 0}$ & Group II, $\mathbf{n = 3 3}$ & Total \\
\hline Up to 40 & $2(6.7 \%)$ & $4(12.1 \%)$ & $6(9.5 \%)$ \\
\hline $41-50$ & $7(23.2 \%)$ & $6(18.2 \%)$ & $13(20.6 \%)$ \\
\hline $51-60$ & $10(33.3 \%)$ & $10(30.3 \%)$ & $20(31.7 \%)$ \\
\hline Over 60 & $11(37.8 \%)$ & $13(39.4 \%)$ & $24(38.2 \%)$ \\
\hline
\end{tabular}

Table II. Distribution of patients in experimental groups depending on the duration of onychomycosis

\begin{tabular}{|c|c|c|c|}
\hline Duration of the disease & Group I, $n=30$ & Group II, n = 33 & Total \\
\hline 1 month -5 years & 10 & 11 & $21(33.3 \%)$ \\
\hline $6-10$ years & 9 & 10 & $19(30.2 \%)$ \\
\hline Over 10 years & 11 & 12 & $23(36.5 \%)$ \\
\hline
\end{tabular}

Table III. Distribution of patients of experimental groups by clinical forms

\begin{tabular}{cccc}
\hline Clinical form & Group I, $\mathbf{n}=\mathbf{3 0}$ & Group II, $\mathbf{n = 3 3}$ & Total \\
\hline Distal-lateral & $17(56.7 \%)$ & $16(48.5 \%)$ & $33(52.4 \%)$ \\
\hline Proximal & $4(13.3 \%)$ & $5(15.1 \%)$ & $9(14.3 \%)$ \\
\hline Total-dystrophic & $9(30.0 \%)$ & $12(36.4 \%)$ & $21(33.3 \%)$ \\
\hline
\end{tabular}


Table IV. Distribution of patients of experimental groups according to the severity of onychomycosis

\begin{tabular}{cccc}
\hline Degree of severity & Group I, $\mathbf{n}=\mathbf{3 0}$ & Group II, $\mathbf{n = 3 3}$ & Total \\
\hline Mild & $11(36.7 \%)$ & $8(24.2 \%)$ & $19(30.1 \%)$ \\
\hline Moderate & $14(46.7 \%)$ & $13(39.4 \%)$ & $27(42.8 \%)$ \\
\hline Severe & $5(16.6 \%)$ & $12(36.4 \%)$ & $17(27.1 \%)$ \\
\hline
\end{tabular}

Table V. Distribution of patients of experimental groups by clinical forms and severity

\begin{tabular}{cccccccc}
\hline \multirow{2}{*}{$\begin{array}{c}\text { Degree of } \\
\text { severity }\end{array}$} & \multicolumn{2}{c}{ Distal-lateral } & \multicolumn{2}{c}{ Proximal } & \multicolumn{2}{c}{ Total-dystrophic } \\
\cline { 2 - 7 } & $\begin{array}{c}\text { Group I, } \\
\mathbf{n = 3 0}\end{array}$ & $\begin{array}{c}\text { Group II, } \\
\mathbf{n = 3 3}\end{array}$ & $\begin{array}{c}\text { Group I, } \\
\mathbf{n = 3 0}\end{array}$ & $\begin{array}{c}\text { Group II, } \\
\mathbf{n = 3 3}\end{array}$ & $\begin{array}{c}\text { Group I, } \\
\mathbf{n = 3 0}\end{array}$ & $\begin{array}{c}\text { Group II, } \\
\mathbf{n}=\mathbf{3 3}\end{array}$ \\
\hline Mild & 9 & 8 & 1 & - & 1 & - & Total \\
\hline Moderate & 8 & 6 & 2 & 2 & 4 & 5 & $27(42.8 \%)$ \\
\hline Severe & - & 2 & 1 & 3 & 4 & 7 & $17(27.1 \%)$ \\
\hline Total & 17 & 16 & 4 & 5 & 9 & 12 \\
\hline
\end{tabular}

Table VI. Evaluation of the therapeutic efficacy of various methods of treatment of patients with onychomycosis of the toes of the experimental groups

\begin{tabular}{|c|c|c|c|c|c|c|c|c|c|c|c|c|c|c|c|c|}
\hline \multirow{3}{*}{ Evaluation of efficacy } & \multicolumn{16}{|c|}{ Weeks } \\
\hline & \multicolumn{2}{|c|}{4} & \multicolumn{2}{|c|}{6} & \multicolumn{2}{|c|}{8} & \multicolumn{2}{|c|}{10} & \multicolumn{2}{|c|}{12} & \multicolumn{2}{|c|}{24} & \multicolumn{2}{|c|}{36} & \multicolumn{2}{|c|}{48} \\
\hline & I & II & I & II & I & II & I & II & I & II & I & II & I & II & I & II \\
\hline Healing & 0 & 2 & 0 & 4 & 2 & 7 & 4 & 10 & 7 & 16 & 14 & 21 & 15 & 22 & 17 & 24 \\
\hline Improvement & 2 & 4 & 4 & 9 & 13 & 16 & 18 & 19 & 20 & 15 & 13 & 11 & 13 & 10 & 11 & 7 \\
\hline No changes & 28 & 24 & 16 & 20 & 15 & 10 & 8 & 4 & 3 & 2 & 3 & 1 & 2 & 1 & 2 & 2 \\
\hline Deterioration & 0 & 0 & 0 & 0 & 0 & 0 & 0 & 0 & 0 & 0 & 0 & 0 & 0 & 0 & & 0 \\
\hline
\end{tabular}

Table VII. Distribution of patients of experimental groups according to the onset of mycological recovery

\begin{tabular}{cccccccc}
\hline \multirow{2}{*}{$\begin{array}{c}\text { Clinical form of } \\
\text { onychomycosis }\end{array}$} & $\begin{array}{l}\text { Groups under } \\
\text { investigation }\end{array}$ & Total & Recovered & Total & Recovered & Total & Recovered \\
\cline { 3 - 7 } Distal-lateral & Group I, $\mathrm{n}=17$ & 9 & $8(88.9 \%)$ & 8 & $4(50 \%)$ & 0 & 0 \\
\cline { 2 - 8 } & Group II, $\mathrm{n}=16$ & 8 & $8(100 \%)$ & 6 & $6(100 \%)$ & 2 & $2(100 \%)$ \\
\hline \multirow{2}{*}{ Proximal } & Group I, $\mathrm{n}=4$ & 1 & 0 & 2 & $1(50 \%)$ & 1 & 0 \\
\hline \multirow{2}{*}{ Rotal-dystrophic } & Group II, $\mathrm{n}=5$ & 0 & 0 & 2 & $1(50 \%)$ & 3 & $2(66.7 \%)$ \\
\hline & Group I, $\mathrm{n}=9$ & 1 & 0 & 4 & $1(25 \%)$ & 4 & $1(25.0 \%)$ \\
\hline & Group II, $\mathrm{n}=12$ & 0 & 0 & 5 & $2(40.0 \%)$ & 7 & $3(42.9 \%)$ \\
\hline
\end{tabular}

Table VIII. Terms of achieving mycological recovery in groups depending on the clinical form

\begin{tabular}{|c|c|c|c|c|c|c|c|c|c|}
\hline \multirow{2}{*}{$\begin{array}{l}\text { Clinical form of } \\
\text { onychomycosis }\end{array}$} & \multirow{2}{*}{$\begin{array}{l}\text { Group under } \\
\text { investigation }\end{array}$} & \multicolumn{8}{|c|}{ Weeks } \\
\hline & & 4 & 6 & 8 & 10 & 12 & 24 & 36 & 48 \\
\hline \multirow{2}{*}{ Distal-lateral } & $\begin{array}{c}\text { Group l, } \\
\mathrm{n}=17\end{array}$ & - & - & $\begin{array}{c}2 \\
(11.8 \%)\end{array}$ & $\begin{array}{c}6 \\
(35.3 \%)\end{array}$ & $\begin{array}{c}8 \\
(47.1 \%)\end{array}$ & $\begin{array}{c}9 \\
(52.9 \%)\end{array}$ & $\begin{array}{c}12 \\
(70.6 \%)\end{array}$ & $\begin{array}{c}14 \\
(82.4 \%)\end{array}$ \\
\hline & $\begin{array}{c}\text { Group II, } \\
n=16\end{array}$ & - & $\begin{array}{c}1 \\
(6.3 \%)\end{array}$ & $\begin{array}{c}7 \\
(43.8 \%)\end{array}$ & $\begin{array}{c}7 \\
(43.8 \%)\end{array}$ & $\begin{array}{c}10 \\
(6.3 \%)\end{array}$ & $\begin{array}{c}16 \\
(100 \%)\end{array}$ & $\begin{array}{c}16 \\
(100 \%)\end{array}$ & $\begin{array}{c}16 \\
(100 \%)\end{array}$ \\
\hline \multirow{2}{*}{ Proximal } & $\begin{array}{c}\text { Group l, } \\
\mathrm{n}=4\end{array}$ & - & - & - & - & $\begin{array}{c}1 \\
(25 \%)\end{array}$ & $\begin{array}{c}1 \\
(25 \%) \\
\end{array}$ & $\begin{array}{c}2 \\
(50 \%)\end{array}$ & $\begin{array}{c}2 \\
(50 \%) \\
\end{array}$ \\
\hline & $\begin{array}{l}\text { Group II, } \\
\mathrm{n}=5\end{array}$ & - & - & $\begin{array}{c}1 \\
(20.0 \%)\end{array}$ & $\begin{array}{c}1 \\
(20.0 \%)\end{array}$ & $\begin{array}{c}2 \\
(40.0 \%)\end{array}$ & $\begin{array}{c}2 \\
(40.0 \%)\end{array}$ & $\begin{array}{c}3 \\
(60.0 \%)\end{array}$ & $\begin{array}{c}3 \\
(60.0 \%)\end{array}$ \\
\hline \multirow{2}{*}{ Total-dystrophic } & $\begin{array}{c}\text { Group I, } \\
\mathrm{n}=9\end{array}$ & - & - & - & - & $\begin{array}{c}1 \\
(11.1 \%)\end{array}$ & $\begin{array}{c}3 \\
(33.3 \%)\end{array}$ & $\begin{array}{c}4 \\
(44.4 \%)\end{array}$ & $\begin{array}{c}6 \\
(66.7 \%)\end{array}$ \\
\hline & $\begin{array}{c}\text { Group II, } \\
n=12\end{array}$ & - & - & $\begin{array}{c}1 \\
(8.3 \%)\end{array}$ & $\begin{array}{c}1 \\
(8.3 \%)\end{array}$ & $\begin{array}{c}4 \\
(33.3 \%)\end{array}$ & $\begin{array}{c}8 \\
(66.7 \%)\end{array}$ & $\begin{array}{c}9 \\
(75.0 \%)\end{array}$ & $\begin{array}{c}9 \\
(75.0 \%)\end{array}$ \\
\hline
\end{tabular}


The distribution of patients into groups according to the duration of the disease is shown in Table II.

The obtained data show that the vast majority of patients (42 subjects $-66.7 \%$ ) suffered from onychomycosis for more than 6 years.

Concomitant disorders, including those affecting the course of onychomycosis, pharmacodynamics and pharmacokinetics of antifungal agents was observed in all the patients. Concomitant diseases predominantly included varicose veins in 40 (63.4\%), impairments of the cardiovascular system with peripheral circulatory disorders in 38 (60.3\%), diseases of the endocrine system in $36(57.1 \%)$, including type I diabetes in 18 (28.6\%), disorders of the gastrointestinal tract, found in 25 patients (36.7\%), chronic diseases of the ENT organs in 17 (27.0\%), obliterating endarteritis in 11 (17.4\%).

The number of affected nails in most patients ranged from 3 to 10 , and in most $(34-53.9 \%)$ the infection affected 4-6 fingers. Lesions of 10 nails were noted in 10 patients (15.9\%).

Distal-lateral clinical form of onychomycosis was diagnosed in most patients (33 people $-52.4 \%$ ), proximal in 9 (14.3\%), total-dystrophic in 21 (33.3\%).

Data on the distribution of patients with onychomycosis by clinical forms are given in Table III.

Positive culture study was obtained in 34 patients (53.9\%), of which 18 patients belonged to group I, 16 to group II. Pure cultures of dermatophytes predominated. Dermatophyte-yeast flora was mixed in 10 (29.4\%) patients. The obtained data coincide with the data of other authors, who claim that under the most favorable conditions the culture of the fungus can be obtained in no more than half of patients [12-14].

Patients with a negative culture study were clinically found dermatophytic onychomycosis with no nail inflammation, severe hyperkeratosis, lesions of a large number of nails, noticeable manifestations of squamous-hyperkeratotic type mycosis of the toes.

All the patients after the examination were divided according to the severity of the pathological process, taking into account the presence of pathogenically significant comorbidities: 19 patients (30.1\%) with mild severity, moderate in $27(42.8 \%)$, severe in $17(27.1 \%)$.

The distribution of patients with onychomycosis of the toes by groups by severity is shown in Table IV.

It was found that the group with mild lesions of the nail plates (19 subjects) also included patients with predominantly distal-lateral clinical form (17 subject) (Table III), characterized by the presence of whitish, yellowish or grayish-yellow spots and streaks in the distal lateral part of the nail.

The largest number of patients had a moderate degree of lesion (27 subjects $-42.8 \%$ ), of whom 14 patients had a distal-lateral clinical form, 4 proximal and 9 total dystrophic. The nail plates in these patients were dirty gray, thickened, partially or completely destroyed from the free edge. Significant subungual hyperkeratosis was observed, which in some patients turned into pachyonychia.
In severe lesions of the nail plates (17 subjects - 27.1\%) the vast majority of patients had a total dystrophic form of nail lesions (11 subjects) and proximal (4), 2 patients were found to have distal-lateral.

The proximal form of the lesion was diagnosed in all patients who had received prior therapy for onychomycosis. In this case, the nail plates were dirty yellow, easily crumbled on the sides and on the free edge. In some patients, hyperkeratosis led to onychogryphosis. Subungual changes were registered only in patients with distal-lateral and total-dystrophic form of onychomycosis (Table V).

The patients were observed for 48 weeks.

Patients with a complex recurrent course and in the presence of concomitant pathogenically significant diseases were treated comprehensively to correct the identified disorders.

From the $4^{\text {th }}$ week of treatment and then once every 2 weeks, a mycological examination of the cut nails was performed. The clinical condition of patients was studied according to the following criteria: healing, improvement, no changes, deterioration. As can be seen from Table VI, the deterioration of the pathological process was not observed in any patient. 48 weeks after the start of treatment in 2 patients $(6.7 \%)$ of Group I and 2 patients of Group II $(6.4 \%)$ no changes were observed in the course of the pathological process, which is associated with a violation of the treatment regimen, the use of folk remedies and worsening of the concomitant disease.

The overall effectiveness of therapy reached $56.7 \%$ in Group I and $72.7 \%$ in Group II.

The dependence of therapeutic efficacy on the severity of onychomycosis and the timing of mycological recovery is noteworthy.

Thus, in mild lesions, mycological recovery occurred in 8 patients with distal-lateral form of Group I, which amounted to $72.2 \%$, and in all $100 \%$ of patients of Group II.

In the group of patients with moderate lesions, mycological recovery occurred in 4 patients (50\%) with distal-lateral clinical form in Group I and in all 6 patients (100\%) of Group II. In patients with the proximal form of the disease, mycological negativity was observed in 1 patient in each group, which amounted to $50 \%$ of cases in each case.

Mycological recovery was determined in the total dystrophic form of moderate lesions in 1 patient (25\%) in Group I and $2(40 \%)$ in Group II of the subjects under investigation.

The study showed mycological recovery in severe lesions in 25\% (1) of cases of Group I and $42.9 \%$ in Group II (7 subjects) (Table VII).

Assessment of the timing of mycological recovery depending on the clinical form showed that in patients with distal-lateral onychomycosis who received topical therapy in the form of naftifine hydrochloride solution and cream (Group I), mycological recovery was observed at 8 weeks of treatment in $2(11.8 \%)$ patients, after 12 weeks in 8 (47.1\%), after 48 weeks in 14 people (82.3\%) (Table VIII). In patients receiving combination therapy (Group II), the time of negation of the mycological result was much shorter. Mycological recovery in $100 \%$ of patients with this 
form of the disease was observed 24 weeks after treatment. That is, the administration of an agent which improves microcirculation, stimulates tissue respiration and is a metabolic energy corrector (cytoflavin), and an agent that promotes natural regrowth of the nail plate and improves nail structure (mycosan), reduces the duration of clinical and mycological recovery, i.e. increases the effectiveness of therapy.

\section{DISCUSSIONS}

Patients with proximal onychomycosis of Group I the first 8-10 weeks were found to have only some improvement, after 10 weeks mycological recovery was observed in 1 patient (25\%), by the end of treatment (48 weeks) in 2 (50\%), while in Group II patients with this clinical form of improvement it occurred at the $6^{\text {th }}$ week, mycological recovery in 1 patient $(20 \%)$ was observed at the $8^{\text {th }}$ week, at the $48^{\text {th }}$ week mycological negativity occurred in $60 \%$ of cases in 3 subjects.

Regarding patients of Group I with total dystrophic clinical form of onychomycosis, mycological recovery occurred in 1 patient $(11.1 \%)$ at the $12^{\text {th }}$ week from the beginning of treatment, at the end of treatment at the 48th week in $6(66.7 \%)$, while in patients of Group II with a total dystrophic form of nail lesion improvement of clinical manifestations of onychomycosis of the toes occurred in 6 weeks, mycological recovery in 1 patient $(8.3 \%)$ in 8 weeks, in $9(75 \%)$ at the end of the observation at the $48^{\text {th }}$ week.

Thus, mycological recovery in patients of Group I occurred at the end of follow-up in 48 weeks in $73.3 \%$ of cases (in 22 subjects), in Group II in $84.8 \%$ (in 28 subjects), with 5 patients in Group I and 4 patients of Group II showing improvement of clinical signs of onychomycosis. The obtained data on the lag of clinical signs of onychomycosis from mycological negativity coincide with the data of foreign researchers [15-17]. This is due to the presence of onychodystrophic processes in the nail plate, associated with pathogenically significant disorders, the age of patients, which requires the use of further tools that improve the structure of the nail plate and blood circulation.

Therefore, in the complex treatment of patients with onychomycosis, especially distal-lateral and total-dystrophic forms of both mild and severe lesions, it is advisable to use along with topical antifungal drugs containing rye enzyme extract, which improves the structure of nail plates, and metabolic energy - an agent that improves microcirculation in the terminal phalanges.

\section{CONCLUSIONS}

Studies have shown the high therapeutic efficacy of the developed comprehensive method of treatment of patients with onychomycosis with contraindications to systemic antifungals, which includes the use of naftifine hydrochloride solution and cream, nail kit containing rye enzyme extract and metabolic energy corrector, which allows to achieve clinical and mycological recovery in
$72.7 \%$ of patients, although the use of only topical antifungal solution and cream shows therapeutic efficacy in only $56.7 \%$ of patients.

The use of rye enzyme extract and metabolic energy corrector in the complex treatment of patients with onychomycosis contributes to the onset of earlier mycological negativity due to the synergism of agents and conditions of their use and increases the effectiveness of therapy for patients with onychomycosis with contraindications to systemic anticoagulants.

Thus, the developed complex method for patients with onychomycosis with comorbid conditions is a priority in the treatment of onychomycosis.

\section{REFERENCES}

1. Havlickova A., Czaika V.A., Friedrich M. Epidemiological trends in skin mycoses worldwide. Mycoses. 2008;51(4):2-15.

2. Dyudyun A.D., Gladyishev V.V., Polion N.N. et al. Effektivnost i bezopasnost lecheniya patsientov s onihomikozom [Efficiency and safety of treatment of patients with onychomycosis]. Retsept. 2018;21(5):693-702. ( in Russian)

3. Kasyimov 0.I., Salimov B.M., Kasyimov A.0. Kliniko-immunologicheskie osobennosti onihomikoza u lits pozhilogo i starcheskogo vozrasta [Clinical and immunological features of onychomycosis in the elderly]. Nauchno-prakticheskiy zhurnal TIPPMK. 2012;2:17-22. (in Russian)

4. Gerasimchuk E.V. Rol sovremennyih naruzhnyih protivogribkovyih preparatov v lechenii mikoticheskoy infektsii kozhi stop i nogtey u gerontologicheskih bolnyih [The role of modern external antifungal drugs in the treatment of mycotic infections of the skin of the feet and nails in gerontological patients]. Klin. gerontol. 2016;22(7-8):63-5. ( in Russian)

5. Elewski B.E., Cantrell W., Lin T. Is Severity of Disease a Prognostic Factor for Cure Following Treatment of Onychomycosis? J Drugs Dermatol. 2018;17(2):175-178.

6. Kaul S., Yadav S., Dogra S. Treatment of dermatophytosis in elderly, children, and pregnant women. Indian Dermatol Online J. 2017;8(5):310-8.

7. Lytynska T.0. Onikhomikoz: suchasni mozhlyvosti topichnoi terapii [Onychomycosis: modern possibilities of topical therapy]. Ukr. zhurn. dermatolohii, venerolohii, kosmetolohii. 2019;2:88-92. (in Ukrainian)

8. Perlamutrov Yu.N., Olhovskaya K.B., Lyapon A.O. Novoe napravlenie $v$ naruzhnoy terapii onihomikozov [A new direction in the external treatment of onychomycosis]. Allergologiya. Dermatologiya. 2014;5:47-50. ( in Russian)

9. Sergeev A.Yu., Sergeev Yu.V. Gribkovyie infektsii: Rukovodstvo dlya vrachey [Fungal Infections: A Guide for Physicians]. Moskva: Binosh; 2008. 280 p. ( in Russian)

10. Ivanov 0.L., Sergeev V.Yu., Sergeev A.Yu. et al. Sovershenstvovanie laboratornoy diagnostiki onihomikozov na osnove metoda polimeraznoy tsepnoy reaktsii [Improving the laboratory diagnosis of onychomycosis based on the polymerase chain reaction method]. Ros. zhurn. kozhnyih i venericheskih bolezney. 2009;4:6-11. ( in Russian)

11. Brillowska-Dabrowska A., Saunte D.M., Arendrup M.C. Five-hour diagnosis of dermatophyte nail infections with specific detection of Trichophyton rubrum. J. Clin. Microbiol. 2007;45(4):1200-1204.

12. Kasihina E.I. Ratsionalnyiy vyibor topicheskogo antimikotika [The rational choice of topical antimycotics]. Klinicheskaya dermatologiya i venerologiya. 2015;2:87-91. ( in Russian) 
13. Tlish M.M., Kuznetsova T.G., Psavok F.A. Etiological features of onychomycosis in the Krasnodar Territory. The choice of method of systemic therapy [Etiological features of onychomycosis in the Krasnodar Territory. The choice of systemic therapy]. Bulletin of Dermatology and Venereology. 2016;92(5):84-89. (in Russian)

14. Yunusova E.I., Yusupova L.A., Garaeva Z.Sh., et al. Osobennosti sovremennogo techeniya i terapii onihomikoza [Features of the modern course and treatment of onychomycosis]. Lechaschiy vrach. 2017;11:7-10. ( in Russian)

15. Kotrehova L.P., Raznatovskiy K.I., Tsurupa E.N. Flukonazol v terapii bolnyih onihomikozom stop, protekayuschim s prognosticheski neblagopriyatnyimi klinicheskimi proyavleniyami [Fluconazole in the treatment of patients with foot onychomycosis occurring with prognostically unfavorable clinical manifestations]. Klinicheskaya dermatologiya i venerologiya. 2015;3:46-51. ( in Russian)

16. Tsurupa E.N., Kotrehova L.P., Raznatovskiy K.I., et al. Plesnevoy onihomikoz stop u bolnyih pozhilogo i starcheskogo vozrasta, prozhivayuschih v Sankt-Peterburge i Leningradskoy oblasti [Mold onychomycosis of the feet in elderly and senile patients living in St. Petersburg and the Leningrad Region]. Dermatologiya v Rossii. 2018;(3):89-91. ( in Russian)

17. Veselov A.V., Honraet K. Novyiy podhod k topicheskoy terapii onihomikozov [A new approach to the topical treatment of onychomycosis]. Klin mikrobiol antimikrob himioter. 2013;15(1):23-34. ( in Russian)

\section{ORCID and contributionship:}

Kseniia Suprun: 0000-0003-2540-9147 A-D

Yanina Kutasevych: 0000-0001-8706-1487 A,F

Iryna Oliinyk: 0000-0002-6408-830X ${ }^{B, D, F}$

Oleksii Bilozorov: 0000-0002-8721-8111 ${ }^{B, E}$

Iryna Mashtakova: 0000-0002-3592-6896 ${ }^{B, E}$

Olga Stuliy: 0000-0002-7445-3606 ${ }^{B}$

\section{Conflict of interest:}

The Authors declare no conflict of interest.

\author{
CORRESPONDING AUTHOR \\ Yanina Kutasevych \\ SE «Institute of dermatology and \\ venereology of NAMS of Ukraine» \\ 7/9 Chernyshevska st., 61057 Kharkiv, Ukraine \\ tel: +38(050)6357202 \\ e-mail: otdderm@ukr.net
}

Received: 14.09 .2020

Accepted: 02.06.2021

\footnotetext{
A - Work concept and design, B - Data collection and analysis, C - Responsibility for statistical analysis, D-Writing the article, $\mathbf{E}$-Critical review, $\mathbf{F}$ - Final approval of the article
} 